\title{
READINESS OF TOURISM HUMAN RESOURCES FACING THE INDUSTRIAL REVOLUTION 4.0: A CASE STUDY AT FURAMA XCLUSIVE OCEAN SEMINYAK HOTEL
}

\author{
Wirawan I Made Adi ${ }^{\star}$, Gorda A.A.N. Oka Suryadinatha \\ Undiknas Graduate School, Denpasar, Indonesia \\ *E-mail: adiwirawan2908@gmail.com
}

\begin{abstract}
The use of interface systems according to the model of industry 4.0 at Furama Xclusive Ocean Seminyak requires training of employees, especially the front office and sales marketing where the operation of the system will not be maximized without the support of skilled human resources. Therefore, the use of a real-time interface based system requires more or less than a year in the setup and training process. The objective of this study was to find out the readiness of tourism human resources facing the industrial revolution 4.0 at the Furama Xclusive Ocean Seminyak and to determine the factors that support the readiness of tourism human resources facing the industrial revolution 4.0 at the Furama Xclusive Ocean Seminyak. The result found that the readiness of tourism human resources facing the industrial revolution 4.0 at the Furama Xclusive Ocean Seminyak is pretty good. All employees working in their respective fields have been given optimal training in the use of systems in each department. The factors that support the readiness of tourism human resources facing the industrial revolution 4.0 at the Furama Xclusive Ocean Seminyak are financial factors and factors that apply the applicable system. To get a system that is ready regarding the industrial revolution 4.0, the stakeholders must make an initial investment which is not small so that the Furama Xclusive Ocean Seminyak becomes one of the hotels that has a more advanced system usage than other hotels.
\end{abstract}

\section{KEY WORDS}

Industry 4.0, human resources, hotel, Bali.

The tourism sector has grown massively and significantly in the last few decades, according to the World Bank, tourism has become Indonesia's core business because tourism is the main driver of national economic growth through foreign exchange, job creation, and increase in national GDP.

Industrial development occurs genetically, artificial intelligence, nanotechnology, robotics, biotechnology, and 3D printing, are the signs of the era of industrial revolution 4.0 (Yahya, 2018). In line with the development of this information technology, in Bali, industry 4.0 has changed the way tourists will travel, ranging from searching and view information (look), booking tour packages that match interest (book) to making online payments (pay). Industry 4.0 needs to be addressed wisely if labor or human resources cannot compete and keep up with developments.

One of the five-star hotels in Badung Regency that has used a 4.0 system in terms of its operational activities is Furama Xclusive Ocean Seminyak. Furama Xclusive Ocean Seminyak is located on Jl. Arjuna No. 88X, Legian, Kuta, Badung Regency, Bali. The location of Furama Xclusive Ocean Seminyak is right across the Seminyak beach, which has an attraction for both domestic and foreign tourists. This stimulates the business development of Furama Xclusive Ocean Seminyak which has a very strategic location.

The use of interface systems according to the model of industry 4.0 at Furama Xclusive Ocean Seminyak requires training of employees especially the front office and sales marketing departments where the operation of the system will not be maximized without the support of skilled human resources. Therefore, the use of a real-time interface based system requires more or less than a year in the setup and training process. 
The phenomenon that occurs at Furama Xclusive Ocean Seminyak is that some HRs in the front office and sales marketing departments have not been proficient in using the system so there are several times of human errors that cause travelers who book do not get suitable rooms, or there are some unregistered requests that cause the travelers who stay overnight complain to the management.

Furthermore, the issue that occurs is that if there is employee turnover or one of the employees resigns and is replaced with a new employee. Intensive training must be given immediately so the new employee can run the system properly and with an immediate time. For that reason, the researcher is interested in conducting current study.

The formulation of the problem to be investigated by the researcher is:

1. How is the readiness of tourism human resources in facing the industrial revolution 4.0 at the Furama Xclusive Ocean Seminyak Hotel?

2. What factors support the readiness of tourism human resources in facing the industrial revolution 4.0 at Hotel Furama Xclusive Ocean Seminyak?

The objectives of this study are:

1) To find out the readiness of tourism human resources in facing the industrial revolution 4.0 at the Furama Xclusive Ocean Seminyak Hotel.

2) To determine the factors that support the readiness of tourism human resources in facing the industrial revolution 4.0 at the Hotel Furama Xclusive Ocean Seminyak.

\section{METHODS OF RESEARCH}

According to Kasali (2014) explains that disruption ultimately creates a new world, digital marketplace. Interestingly, the valuation of a company is no longer based on what is traded by that company alone. The new valuation is currently also holding out prospects that appear to the state of the corporate institution. When the market changes, consumers will change.

In general, the definition of disruption is an innovation that will replace the entire old system with the new ones. Disruption has the potential to replace old players with new ones. Disruption can be seen as something positive because it is a dynamic innovation. This creates the works of the era of disruption that discusses the digital revolution, the communication revolution, and the technological singularity.

A good work assessment of industry 4.0 is a work assessment of industry 4.0 that can produce complete, accurate, and objective information so that later this data or information can be used as material for making a valid decision and policy (Hayat, 2013). These decisions need to be made by management to maintain the performance of human resources that are considered not able to meet performance standards. Therefore, work assessment of industry 4.0 needs to involve a structured and accountable system obtained from evaluated employees, superiors, coworkers, and customers described by Kasali (2014) as follows:

- Employees who are evaluated in which the assessment is conducted on people who want to be evaluated which is a test of honesty for the employees and form of responsibility for what has been stated. The employee in charge will provide a separate assessment as it is according to the tasks that have been done.

- Immediate superior is a person who acts as a leader in an organization giving orders or tasks, giving direction, coordinating a task, supervising, and evaluating the performance of human resources in an organization he leads. Information obtained directly from a superior objectively will provide a high-level truth of data information, so that the information is highly valuable in decision-making or policies in an organization.

- Coworkers who have more accurate information than those possessed by superiors where other than they often establish cooperative relationships in doing their job, Coworkers will see direct performance of human resources as it is. However, there are shortcomings where not all coworkers act honestly out of pity or because of the rivalry among coworkers. 
- The customer is the party who most likely to obtain goods or services that are sometimes not following their expectations and desires if the performance of the employee is less satisfactory or poor. They will feel disadvantaged because they have issued a sum of money but do not get the goods or services that have been promised in advance by the company.

All physical and non-physical activities will lead to the work of human resources, both qualitative and quantitative (Suparyadi, 2015). According to Cardy and Selvarajan (2006), they also state that competence is often used as the basis for industrial 4.0 job assessments in an organization or company. Apart from being used as a performance measurement tool, competence is also used to identify behavioral factors that are relevant to job performance and see how work is done (Ozcelik and Ferman, 2006). Assessing and evaluating individual performance through competence will also provide opportunities for self-development. professional for human resources (Ennis, 2008).

Kunartinah and Fajar (2010) state that development is "Every effort to improve labor performance at a particular job that becomes their responsibility or one job that is related to their work. Training is more related to improving the skills of human resources/workers who have occupied a certain job or task so that more emphasis on skills."

Santoso (2014) explains that development is "activity to maximize learning opportunities and introduce more empowerment, feedback, and mechanisms of strengthening resources into a system so human resources is not only have one role but several roles so that effectiveness will emerge in a company."

Turere (2010) states that the human resource development methods carried out by an organization can be divided into two main methods, namely:

- Training. This training is a process of teaching human resources in accordance with the basic skills needed to carry out the work that is ordered. Ardana, et al (2013) stated that training is a method used by organizations to develop and improve technical skills in implementing human resources. Rivai (2009) also states that training is part of the learning process to improve skills outside the education system in a short time with a method that prioritizes theoretical practice. Training methods that can be implemented include on the job training and off the job training. On the job training is a process of on-the-job training to learn and imitate a job under the guidance of a supervisor. According to Rivai (2009) and Suparyadi (2015), on the job training can be based on four methods, namely coaching, demonstration and example demonstration, job rotation, and project. According to Rivai (2009) and Suparyadi (2015), the off the job training method consists of vestibules, lectures, case study methods, role playing, and internships.

- Education. The educational method in the narrow sense is to increase the skills and abilities of managers to lead their subordinates effectively. An effective manager in his position will get optimal results. This is what motivates companies to provide education for their managerial human resources. Ardana, et al. (2013) stated that education is a method used by organizations to develop and increase knowledge about the work to be carried out. Rivai (2009) also states that the educational process is part of the learning process to increase knowledge in a short time with a method that prioritizes theoretical application. According to Sikula (2011) there are educational methods that can be used to increase employee knowledge, namely coaching and Counseling, Junior Board of Executive or Multiple Management, Committee Assignment, and Business Games Business games

Spencer (2012) states that competence is a combination of knowledge, skills, and values/attitudes/behavior of individuals that can make the individual able to fulfill what is required by their job by achieving the expected results.

According to Spencer (2012), the competency model is referred to as The Ice Berg Model. In the competency model, Spencer revealed that competencies from knowledge and skills are easier to develop if both of these are evaluated because they will increase competence. The Spencer Dictionary in Sadana (2015), Harjanti (2009), Wibowo (2007) 
divides competencies into twenty types of competencies but only seven will be used in this study based on the phenomena that occur among others are:

1. Achievement orientation $(\mathrm{ACH})$ is the degree of concern of an employee to their job, so they are motivated to try to work better or above standards. People who usually have the desire for achievement have high consistent principles in doing their duties.

2. Organizational commitment (OC) is the ability and desire possessed by someone to connect what will be done based on the needs that must be met, can prioritize organizational goals by doing something to be able to promote organizational goals or to meet organizational needs, and put the mission of organization above their desires or a professional role.

3. Initiative (INT) is an encouragement to act to exceed what is needed or demanded from work, can do something without waiting for orders. This action is done to avoid problems and can create new opportunities in competition. With this initiative can also improve or increase the results of the work assigned.

4. Teamwork and cooperation (TW). Teamwork and cooperation (TW) mean the willingness possessed by someone to work cooperatively with other parties, feeling themselves as part of teamwork so that they want to work together and they become more competitive in completing the assigned tasks.

5. Customer service orientation (CSO) reflects the desire to help or serve others to meet their needs. The focus of this competency is on the efforts to meet the needs of customers or clients. Customers here can be actual customers or other parties in the organization. Customer service orientation is more oriented to service and assistance, focus on the client's needs, partner with clients, focus on end-users, and attention to customer satisfaction.

6. Team leadership (TL) is the willingness to act as a team leader or another group. This understanding is related to the desire to lead others so that the work can be done immediately and properly.

7. Self-control (SCT) is the ability to control emotion to prevent negative actions when there are life's problems, especially when facing challenges or rejection from others or when working under pressure. The existence of strong self-control will produce a good performance in completing the assigned tasks.

This study was conducted at Furama Xclusive Ocean Seminyak located at Jl. Arjuna No. 88X, Legian, Kuta, Badung Regency, Bali 80361. The researcher chose Furama Xclusive Ocean Seminyak because the hotel has used a real-time and integrated online system so it is in line with industry 4.0 trends.

This study used qualitative and quantitative data types. Qualitative data obtained from interviews and documents in the company (Sugiono, 2012) in the form of field observations and the results of in-depth interviews with informants. Quantitative data is data obtained in the form of numbers (Sugiyono, 2012) namely room occupancy rates and data of the employees who are ready to compete for industry 4.0.

Data sources used in this study are primary data and secondary data. Primary data in this study are the results of interviews at the research location. Secondary data in this study are documents in the form of policy regulations regarding the condition of the company in general after the era of industry 4.0, room occupancy rates, staff education levels, and data on employee training.

The research informants selected in this study are the people who are considered the best in providing information to the researcher, namely:

1. Lower class Staff at Furama Xclusive Ocean Seminyak who have utilized the interface and digitization systems in the operational;

2. Middle-class management at Furama Xclusive Ocean Seminyak that has arranged the team to understand the system.

3. High-class management from Furama Xclusive Ocean Seminyak which has utilized the interface and digitization systems in the operational;

Data collection techniques used in this study includes: interviews; observations; documentations. 
Data analysis used in this study is a qualitative data analysis technique in the form of data presentation of narrative text (in the form of field notes), matrices, graphs, networks, and charts (Sugiyono, 2012). Qualitative data analysis using the Miles and Huberman method. The theory of Miles and Huberman in Sugiyono (2012) suggests that the activities in qualitative data analysis are conducted interactively and continuously until complete so that the data is saturated.

\section{RESULTS AND DISCUSSION}

The following is an elaboration of the Industrial revolution 4.0 principles carried out at the Furama Xclusive Ocean Seminyak Hotel:

1. Interoperability (suitability) through the Internet of things (IoT) at the Furama Xclusive Ocean Seminyak Hotel is done by interfacing the entire property management system used by Furama Hotel International. This system is known as a channel manager. The channel manager is one of the systems that will automatically connect between the room availability in the hotel and information received by the head office and provide Internet of public (IoP) to online travel agent business partners to make room sales and reservations instantly via the internet. With this channel manager, the sales and marketing department can market room availability automatically for 24 hours to hundreds of online sales channels such as agoda.com, booking.com, traveloka.com, and many others. The use of artificial intelligence makes all processes can be done by the systems with minimal interference from the human resources to run it.

2. Information transparency of the system used at the Furama Xclusive Ocean Seminyak Hotel enhances the ability of an information system to create a virtual copy of the physical world. For example, property management uses 360 virtual photos for several locations at the Furama Xclusive Ocean Seminyak Hotel. The use of 360 virtual photos can provide the public with complete information on products offered by the Furama Xclusive Ocean Seminyak Hotel such as rooms, restaurants, swimming pools, and other facilities.

3. The technical assistance provided by the system at the Furama Xclusive Ocean Seminyak Hotel is training from vendor channel managers so that senior employees and new employees who have recently joined can use the system more optimally. The use of the channel manager interface system provides online assistance for 24 hours via online chat so that the employees having trouble in using the system can receive assistance to run the system to return to normal.

4. The independent decision of the channel manager system makes its own decisions and performs the tasks as independently as possible so that the employees in the sales and marketing department do not need to monitor room availability continuously. Every reservation will be processed by the system directly so that workers in the front office department can prepare matters related to guest check-in and checkout as well as the housekeeping department in cleaning the room automatically according to the status displayed by the system.

Interviews in this study were conducted to the lower level, middle management, and high management to measure the readiness of tourism human resources facing the industrial revolution 4.0 at Furama Xclusive Ocean Seminyak Hotel. Interview to the lower level at Furama Xclusive Ocean Seminyak Hotel was conducted to front office staff. Interview with Mr. Dipta as the front office staff stated that:

"To prepare myself with the interface system used at the Furama Xclusive Ocean Seminyak Hotel, I and other staff received training from the vendor system such as the Property Management System vendor and Channel manager. Further, several corporate teams based in Singapore provide regular Standard Operating Procedure training to prepare competent human resources in the hotel."

Mr. Dipta as front office staff stated that several training provided by the internal team of Furama Xclusive Ocean Seminyak Hotel had a positive impact on the smooth operation of the hotel. For example, the front office staff does not need to do manual activities such as 
posting guest card because this has been done automatically by the system if the settings have been done correctly and precisely.

The interview to middle-class management namely Mr. Gede as Housekeeping Supervisor stated as follows:

"The use of a system with a guest card that is inputted automatically facilitates the work of the Housekeeping team in cleaning room activities and preparing amenities according to the request. For example, the system has provided input automatically if the guest gets a wine bottle or a complimentary mini-bar. If the work is still done manually like what was done 2 years ago, then there can be human errors such as the front office staff is late to provide check-in and checkout information from guests. This has made the housekeeping staff in disarray in room preparing".

Mr. Gede as Housekeeping Supervisor explained that there are unique points that are still rarely done in other hotels. This makes the work experience better and more efficient from the management and the housekeeping staff team. Unique points offered are several interfaces from agents who immediately know the availability of hotel rooms. This makes the quality of room service more alert and increases the consumers' satisfaction during their stay.

The interview to upper-class management namely Mrs. Fanny as Sales and Ecommerce Director stated as follows:

"Furama Xclusive Ocean Seminyak Hotel is one of the hotels that become part of Furama Hotels International which has international standards that are directly applied and monitored by corporate parties based in Singapore. One of the unique points aside from the inter-system interface that connects the sales system and the room management system is the revenue management system to see the price conditions of competitors more quickly and specifically. Furama Xclusive Ocean Seminyak Hotel has a system called Optima by RateGain, which enables the sales and marketing team to indicate and analyze price positions and competitor rankings in one integrated system. The system helps human resources especially in the sales and marketing department at the Furama Xclusive Ocean Seminyak Hotel to become more efficient in managing the room sales strategy".

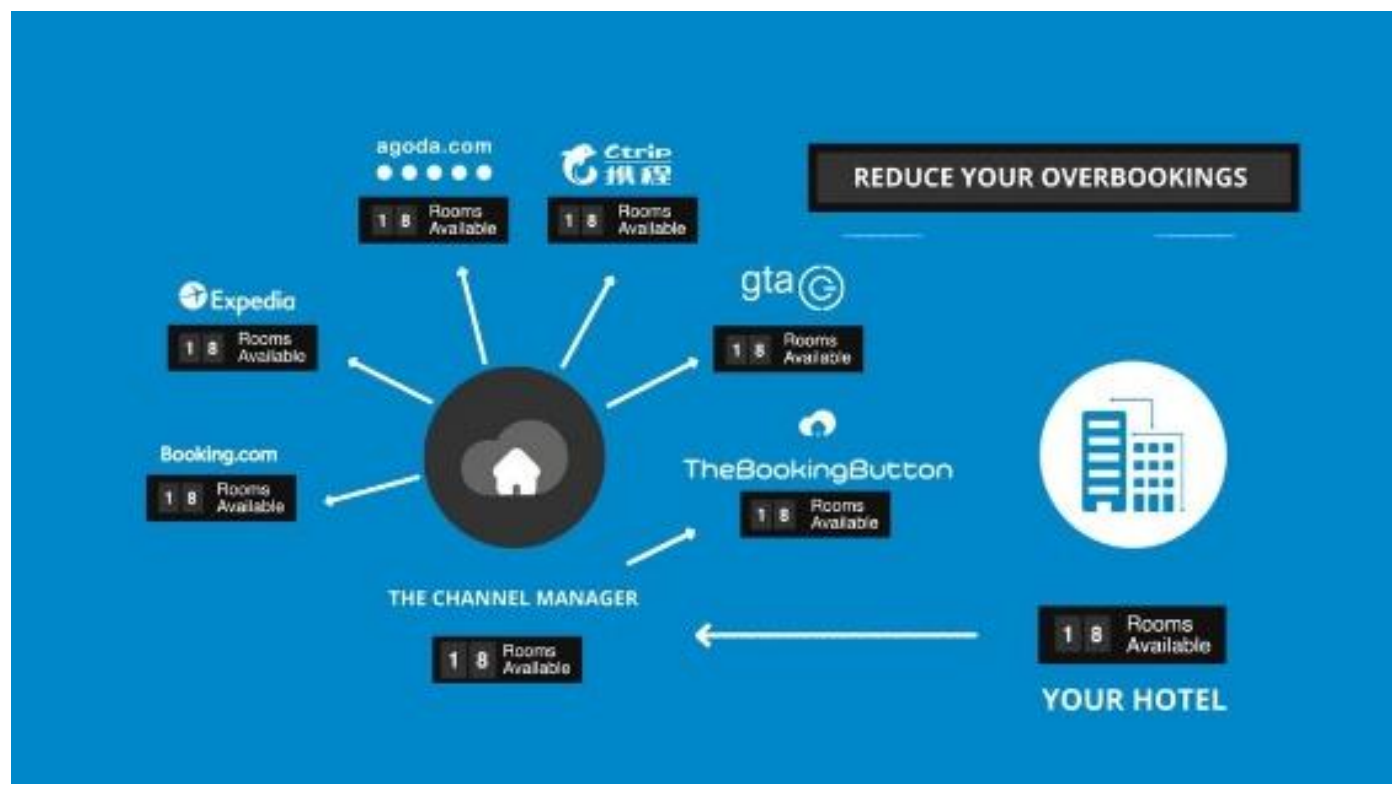

Mrs. Fanny as Sales and E-commerce Director explained that the implementation of the revenue management system was prepared for an efficient and result-oriented workflow. Human resource development in the sales and marketing department will be maximized because HR can interact automatically with the system and coworkers from various other regions online, where communication in terms of work can be done immediately. 


\section{DISCUSSION OF RESULTS}

The readiness of tourism human resources facing the industrial revolution 4.0 at the Hotel Furama Xclusive Ocean Seminyak is pretty good. All employees working in their respective fields have been given optimal training in the use of systems in each department.

One of the examples of this training is training regarding the interface system that is connected to the hotel room inventory system with a head of corporate located in Singapore. The system also automatically updates with room availability at the Furama Xclusive Ocean Seminyak Hotel and sells it directly to the travel agent's online site and hotel website.

The channel manager as one of the systems engaged in artificial intelligence connects the internal company of the Furama Xclusive Ocean Seminyak Hotel with business partners so that business partners of the Furama Xclusive Ocean Seminyak Hotel can market room availability to avoid wrong bookings from potential customers.

The use of the system in industrial revolution 4.0 according to some experts is to improve the work effectiveness of human resources. Therefore, the use of channel manager as one form of industrial revolution 4.0 which is run by the Furama Xclusive Ocean Seminyak Hotel causes employees to be more able to focus on strategic matters such as sales and marketing departments can carry out their tasks to be more focus on sales strategies and are not preoccupied with repetitive matters such as input data on room availability.

Factors that support the readiness of tourism human resources facing industrial revolution 4.0 at the Furama Xclusive Ocean Seminyak Hotel are financial factors and factors that apply the applicable system. To get a system that is ready regarding the industrial revolution 4.0, the stakeholders must make an initial investment which is not small so that the Furama Xclusive Ocean Seminyak Hotel becomes one of the hotels that has a more advanced system usage than other hotels

The factor of initial fund investment by stakeholders from the Furama Xclusive Ocean Seminyak Hotel is expected to bring an appropriate return of investment so that the use of this automated information system can increase company profits. The profit can be achieved as a result of the effectiveness of human resources who work so the management does not need to do high energy of recruitment so that the productivity of each employee can be achieved.

\section{CONCLUSION}

Based on the research results, the conclusion is as follows:

1. The readiness of tourism human resources facing the industrial revolution 4.0 at the Furama Xclusive Ocean Seminyak Hotel is pretty good. All employees working in their respective fields have been given optimal training in the use of systems in each department. One example of this training is training on the interface system that is connected to the hotel room inventory system with a head of corporate located in Singapore. The system also automatically updates with room availability at the Furama Xclusive Ocean Seminyak Hotel and sells it directly to the travel agent's online site and hotel website.

2. Factors that support the readiness of tourism human resources facing the industrial revolution 4.0 at the Hotel Furama Xclusive Ocean Seminyak are financial factors and factors that apply the applicable system. To get a system that is ready regarding the industrial revolution 4.0, the stakeholders must make an initial investment which is not small so that the Furama Xclusive Ocean Seminyak Hotel becomes one of the hotels that has a more advanced system usage than other hotels.

\section{REFERENCES}

1. Ardana, I K., N.W. Mujiati., dan I.W.M Mudiartha.(2012).Manajemen sumber daya manusia. Yogyakarta: Graha Ilmu. 
2. Aviananda, S. Junisa. 2014. Laporak Kerja Praktik Evaluasi Siistem Maintenance Jaringan Perpipaan di Denpasar Sewerage Development Project. Fakultas Teknik Sipil dan Lingkungan Institut teknologi Bandung.

3. Cardy, R.L., and . Selvarajan T.T. (2006). Competencies: Alternative Frameworks for Competitive Advantage. Business Horizons.Journal of Service Science and Management.Vol. 49 No. 3, p: 235-24.

4. Danny, A. Tilon. (2013). Pelatihan Dan Pengembangan Sumber Daya Manusia Pada Restoran A\&W Di City Of Tomorrow Surabaya.Jurnal Program Manajemen Bisnis. Jurnal Fakultas Ekonomi Manajemen Sumber Daya Manusia. Vol. 1 No.3.

5. David, Fred. 2009. Manajemen Strategis. Salemba Empat, Karta.

6. Djumadi. 2006. Hukum Pemburuhan Perjanjian Kerja. PT. Raja Grafindo Persada, Jakarta.

7. Ennis,Michelle. (2008). A Review of the Literature and The Role of the Employment and Training Administration (ETA). Division of Research and Evaluation Office of Policy Development and Research Employment and Training Administration U. S. Department of Labor. p:1-25.www.ejournal.co.uk/article/8Phkspt/ennis diakses pada 3 April 2017.

8. Fuanida, Afni., (2012), Pengaruh Pelatihan, Disiplin Kerja, dan Motivasi Terhadap Produktivitas Kerja Karyawan Cv. Sapu Dunia Semarang. Jurnal Ilmu Administrasi Bisnis, Vol. 1, No. 2.

9. Harjanti, Sari (2009) .Pengaruh Kompetensi dan Motivasi terhadap Kinerja Pejabat Struktural Eselon III dan IV di Sekretariat Negara Republik Indonesia. Tesis Fakultas IImu Sosial dan Politik Universitas Indonesia.

10. Hasibuan, Malayu S.P. (2005).Manajemen Sumber Daya Manusia. Edisi Revisi. Bumi Aksara, Jakarta.www.belajarkepegawaian.com/127313/index. diakses pada tanggal 5 April 2017.

11. Hatumale, Matius. (2013). Implementasi Kenijakan Pengembangan Sumber Daya Manusia dan Dampaknya Terhadap Kinerja Aparatur. Governance. Vol.5 No.1.

12. Kasali, Rhenald (2014). Disruption. Jakarta. Penerbit Mizan.

13. Kasali, Rhenald (2014). Tommorow is Today. Jakarta. Penerbit Mizan.

14. Kunartinah dan FajarSukoco (2010). Pengaruh Pendidikan Dan Pelatihan, Pembelajaran Organisasi Terhadap Kinerja Dengan Kompetensi Sebagai Mediasi. Jurnal Bisnis dan Ekonomi.Vol. 17 No.1.

15. Mahmudi.(2010). Manajemen Kinerja Sektor Publik. Yogyakarta : UPP STIM YKPN.

16. Mangkunegara, A.A. Anwar Prabu (2004). Manajemen Sumber Daya Manusia Perusahaan. Bandung : Remaja Rosda Karya.

17. Moeheriono. (2012). Pengukuran Kinerja Berbasis Kompetensi (cetakan kedua). Jakarta: Ghalia Indonesia.

18. Moenir.(2008). Manajemen Pelayanan Umum di Indonesia. Jakarta : PT. Bumi Aksara.

19. Nadiasa, Mayun. (2014).Kapasitas Jenuh Instalasi Pengolahan Air Limbah Denpasar Sewerage Development Project (DSDP).Jurnal Ilmiah Teknik Sipil: Vol.15 No.2 p:123130.

20. Notoadmojo, Soekidjo. 2009. Pengembangan Sumber Daya Manusia. Rineka Cipta, Jakarta.

21. Notoatmodjo. (2013). Pengolahan Limbah Cair. Jakarta: Haji Masagung.

22. Nurmianto, Eko., Nurhadi Siswanto, SanusiSapuwan.(2006). Perancangan Penilaian Kinerja Karyawan Berdasarkan Kompetensi Spencer Dengan Metode Analytical Hierarchy Process" (Studi Kasus di Sub Dinas Pengairan, Dinas Pekerjaan Umum, Kota Probolinggo). Jurnal Teknik Industri. Vol 8 No 1 h: 40-53.

23. Ozcelik dan Ferman. (2006). Competency Approach to Human Resource Management Outcomes and Contributions in a Turkish Cultural Context. Human Resource Development Review Vol 5 No.1 p : 72-91.

24. Pasolong, Harbani. (2010). Teori Administrasi Publik. Bandung: Alfabeta.

25. Peraturan Bersama Gubernur Bali, Bupati Badung dan Walikota Denpasar Nomor 37 A Tahun 2006, Nomor 1 Tahun 2005, Nomor 36 A Tahun 2006 tentang Pengolahan Bersama Sistem Air Limbah Perpipaan (Sewerage system). 
26. Peraturan Daerah No 4 Tahun 2011 tentang Organisasi dan Tata Kerja Perangkat Daerah.

27. Peraturan Gubernur Bali No 100 thn 2011 tentang Organisasi dan Rincian Tugas Pokok Unit Pelaksana Teknis di Lingkungan Dinas pekerjaan Umum Provinsi Bali.

28. Peraturan Gubernur Bali Nomor 134 Tahun 2016 . Honorarium dan Satuan Biaya pada Perangkat Daerah di Lingkungan Pemerintahan Provinsi Bali.

29. Peraturan Menteri Dalam Negeri Nomor 6, Tahun 61 Tahun 2007 tentang Pedoman Teknis Pengelolaan Keuangan Bdan LayananUmumDaerah.

30. Prawirosentono, Suyadi. (2010). Manajemen Sumberdaya Manusia: Kebijakan Kinerja Karyawan: Kiat Membangun Organisasi Kompetitif Era Perdagangan Bebas Dudia (Edisi 2). Yogyakarta : BPFE.

31. Rivai, V. (2009).Manajemen Sumber Daya Manusia Untuk Perusahaan.Jakarta: Raja Grafindo Persada.

32. Sadana, Stefanus M.S (2015). Mendesain Ulang Kompetensi Manajemen Sumber Daya Manusia Organisasi Perbankan (Riset Tindakan Berbasisa Soft Systems Methodelogy pada Bank BTN). Disertasi Fakultas IImu Sosial dan Politik Universitas Indonesia.

33. Santoso, Thomas. (2014). Analisis Pelatihan Dan Pengembangan Sumber Daya Manusia Di Pt Wahana Kosmetika Indonesia.Jurnal Program Manajemen Bisnis Universitas Petra. Vol 2 No.2.

34. Shakeel, A.Khan., MuazzamAli, Hussain, Hafiz Faraz Hussain, Bilal Safdar. 2015. Impact of Employee Training and Motivation on Business Development in Banking Sector: Study Conducted in Pakistan. American Journal of Business, Economics and Management. Vol 3 No. 5 p: 241-249.

35. Soedarmoko, R. 2008. Pderlindungan Pekerja/Buruh dalam perjanjian Kerja Waktu tertentu (PKWT) Sejak Berlakunya Undang-Undang Nomor 13 Tahun 2003 tentang ketenagakerjaan. Tesis Magister Kenotariatan Program Pascasarjana Universitaas Diponegoro Semarang.

36. Sugijono. 2015. Penilaian Kinerja dalam Manajemen Sumber Daya Manusia. Orbith. Vol 1. No.3.

37. Sugiyono.(2012). Metode Penelitian Pendidikan Pendekatan Kuantitatif, Kualitatif Dan R\&D. Bandung: Alfabeta.

38. Suparyadi, H. (2015). Manajemen Sumber Daya Manusia: Menciptakan Keunggulan Bersaing Berbasis Kompetensi SDM.Yogyakarta: ANDI OFFSET.

39. Turere, Verra Nitta. (2010).Pengaruh Pendidikan Dan Pelatihan Terhadap Peningkatan Kinerja Karyawan Pada Balai Pelatihan Teknis Pertanian Kalasey. Jurnal EMBA. Vol.17 No.1. 